\title{
EXPLORATORY STUDY ON DIDACTIC ASPECTS USED IN SCIENTIFIC-TECHNICAL (STEM) DISSEMINATION CONFERENCES FOR STUDENTS OF SECONDARY EDUCATION
}

\author{
Joaquín Fuentes-del-Burgo (iD, Juan M. Sánchez (D), \\ José A. Ballesteros $\mathbb{D}^{\mathrm{D}}$, José L. González-Geraldo $\mathbb{D}$ \\ Universidad de Castilla-La Mancha (Spain) \\ joaquin.fuentes@uclm.es,JuanManuel.Sanchez@uclm.es,JoseA.Ballesteros@uclm.es, \\ JoseLuis.GGeraldo@uclm.es
}

Received May 2021

Accepted November 2021

\section{Abstract}

The connection between education and a country's economic and social development is unquestionable, and science and technology-related careers are of particular importance. Given the lack of vocations in these degrees, a number of mechanisms have been used to attract students, including science and technology conferences in secondary schools. Focusing on this type of lectures, this article aims to analyse the didactic aspects used by university lecturers who deliver this type of lectures. To this end, 16 teachers were interviewed using a structured interview. From the qualitative analysis of the interviews, we reached a series of results and conclusions, among which we would like to highlight the following: teachers see these lectures as a form of scientific dissemination which also helps to promote the degree courses they teach and serves as a support for attracting students; when choosing the content of the lecture, they mainly take into account the secondary school curriculum, including striking aspects and the results of their own research; the mediums used are mainly visual and supported by Do It Yourself (DIY) techniques; the content is normally presented through presentations or practical laboratory exercises; finally, the documentation provided to students depends on the teacher giving the lecture, and there is no consensus on this point.

Keywords - STEM, Dissemination conferences, Promotion, Didactics.

\section{To cite this article:}

Fuentes-del-Burgo, J., Sánchez, J.M., Ballesteros, J.A., \& González-Geraldo, J.L. (2022). Exploratory study on didactic aspects used in scientific-technical (STEM) dissemination conferences for students of secondary education. Journal of Technology and Science Education, 12(1), 96-111. https://doi.org/10.3926/jotse.1318

\section{Introduction}

University education, along with its clear humanistic base (González-Geraldo, 2014), has an unquestionable connection with economic and social development (Moscovici \& Petrica, 2015) and the continuous change of today's technological society (Tabares-Quiroz \& Correa-Vélez, 2014). This aspect is especially important when dealing with the so-called STEM (Science, Technology, Engineering and 
Mathematics) careers, i.e., those related to Science, Technology, Engineering and Mathematics. There are still barriers and biases (Çalıs, 2020; Roper, 2019) regarding these degrees that need to be addressed.

There is also a growing need for qualified and competent specialists and professionals (Tynybekovna, Meirbekovich, Talgatovna \& Pernebaevna, 2013). In Europe, ever since the European Council adopted the Lisbon Agenda in 2000, a great deal of attention has been paid to the need to foster a dynamic and innovative knowledge-based economy (Kearney, 2011). Furthermore, the role of universities in the implementation of the Sustainable Development Goals (Serrate, Martín, Caballero \& Muñoz, 2020) has not been overlooked.

The Lisbon Agenda goals were based on the "knowledge triangle" of research, innovation and education as essential elements of competitiveness and quality of life (Luzón \& Sevilla, 2010). In this context, it has been argued that the integration of science, technology, engineering and mathematics benefits the economy (Tseng, Chang, Lou \& Chen, 2013).

In spite of the importance of STEM-related degrees, a lack of vocations among secondary school students has become apparent in recent years, which is even more evident in the case of women, leading to a decline in enrolment in these degrees (Nuño \& Rico, 2013; Shevtshenko, Karaulova, Igavens, Strods, Tandzegolskiené, Tūtlys et al., 2017; Trumper, 2006).

The lack of interest in scientific and technical disciplines appears to occur between approximately 11 and 15 years of age and is at its lowest in secondary school students (Gibson \& Chase, 2002; Murphy \& Beggs, 2006; Nuño \& Rico, 2013; Osborne, 2007). In addition, there are reports that girls and young women have lower confidence in their academic skills in mathematics and science, decreasing from primary to secondary education (Rittmayer \& Beier, 2009). In contrast, students who become interested in STEM fields in secondary education are more likely to obtain a university degree in a STEM-related field (Broder, Guilbert, Tinghitella, Murphy, Ghalambor \& Angeloni, 2019).

The increasing reluctance of students to engage in science subjects in their final years of secondary education has important implications for both the continuity of scientific work and the scientific literacy of future generations (Trumper, 2006). This situation raises concerns, as educational programmes focused on motivating students to pursue STEM-related careers at university seem insufficient (Fuesting, Diekman \& Hudiburgh, 2017), making it impossible to meet national demands for professionals in these fields (Jackson, Leal, Zambrano \& Thoman, 2019). In addition to not being able to meet the needs of the labour market, basic knowledge in STEM is necessary for anyone to be able to cope with a number of indispensable operations in the social and economic spheres of everyday life (Pisano, Franckowiak \& Anakkar, 2017).

In an attempt to alleviate the situation, companies, professional organisations and universities are developing various actions aimed at promoting STEM, for instance academies and summer schools (Dutta-Moscato, Gopalakrishnan, Lotze \& Becich, 2014; King, Fisher, Becich, \& Boone, 2017; Marques, Restivo \& Chouzal, 2012), competitions, science clubs and science fairs (Sahin, 2013), offering and conducting technical workshops to secondary schools (Fuentes, Huertas \& Torres, 2019) and science and engineering promotion and outreach programmes (Revuelta, 2012; Riesco \& Cernuda, 2015), an approach that transcends subjects as they are usually considered and that presents both benefits and the challenges to be overcome (Kilty, Burrows, Welsh, Kilty, McBride \& Bergmaier, 2021), especially in terms of consolidating STEM education in the classroom (Çalış, 2020).

The promotion and outreach actions, which are complementary to formal education, include scientific, technical and vocational outreach lectures to foster the interest of younger students (Kearney, 2011). Conferences given by STEM professionals provide indirect learning experiences for students by providing opportunities to observe the practice and performance of STEM professionals in their work (Rittmayer \& Beier, 2009). They seek to foster conversations between students about scientific and technical topics that can increase their interest in a future career in science (Jackson et al., 2019). 
Scientists regularly disseminate their findings at conferences through lectures, but the value of this experience for students in pre-university education is not exactly known (Broder et al., 2019). Furthermore, Tseng et al. (2013) recognise that it is important to build appropriate instructional strategies to enhance students' interest and attitudes towards science, both within and outside the classroom (Chacko, Appelbaum, Kim, Zhao \& Montclare, 2015).

Science and technology generate products (methods, technologies, scientific knowledge, etc.) that are presented in highly specialised formats and contexts that are not intuitively accessible to everyone (Blanco, 2004). Dissemination is a complex activity that attempts to bring scientific and technical knowledge to a non-specialised audience, conveying messages in a language that is accessible and understandable to the target audience, allowing them to incorporate scientific knowledge into their culture (Pacheco, 2003; Orrico, 2012; Corredor \& Socorro, 2014). In addition, in some cases, the aim is to carry out vocational dissemination, close to didactics, in which young people are encouraged to study STEM careers (Bonfil, 2003).

In order to bring science to secondary school students, specialised scientific and technical knowledge needs to be reworked and converted into knowledge suitable for them. The process of didactic transposition of this type of knowledge has to combine and balance the scientific-technical aspects and the educational aspects which, at these levels, may present difficulties of integration (Blanco, 2004). In this context, in order to disseminate science and technology through lectures, it is necessary to know specific action methodologies that facilitate achieving favourable results (Iglesias, García-Frank \& Fesharaki, 2017).

In relation to the situation described above, the aim of this research is to find out about the teaching practices employed by university lecturers in dissemination work. This work has been conducted in the Autonomous Community of Castilla-La Mancha, using a qualitative methodology by asking teachers who give scientific-technical lectures in secondary schools. These types of dissemination actions make it possible to take advantage of all the potential of the already established European Higher Education Area, which from its origins already aimed to link teaching with research (González-Geraldo, Trevitt \& Carter, 2011). The article continues with the methodology section, followed by the discussion and results sections, and ends with the conclusions drawn from the study.

\section{Methodology}

The aim of this research is to find out what didactic aspects are used by university lecturers when giving lectures on popularisation and promotion of science and engineering among secondary school students. The qualitative research carried out does not attempt to develop a theory on the didactics of lectures, but it does seek the characteristics and methods used by lecturers in this type of dissemination activity, such that it can be considered an exploratory study (Carvalho, Scott \& Jeffery, 2005).

The fundamental characteristic of qualitative research is the fact that it allows descriptive data to be obtained (Taylor \& Bogdan, 1992). The aim is to obtain information provided by those involved in the research, trying to find meaning and sense with their answers to the research questions posed, in order to explain complex and multifaceted phenomena that characterise human phenomena (Martínez, 2006; Paz, 2003; Smit, 2002; Urraco, 2007).

The participants in this research are lecturers from the University of Castilla-La Mancha (UCLM) who give outreach lectures to students in secondary schools (SeS). In order to preserve the anonymity of the interviewees, in the discussion and results section the quotes selected from each participant will be identified with a number.

The number of interviewees was achieved by an initial convenience sampling (Bryant \& Charmaz, 2007), interviewing six lecturers belonging to the same centre of the UCLM. These first interviewees were asked to contact other lecturers at the University who give scientific-technical dissemination lectures, thus arriving at the well-known "snowball" effect (Handcock \& Gile, 2011), which made it possible to contact 
specialists in the subject matter addressed, who provide a picture of the social universe to be investigated (Izcara, 2014).

The sample size ( $n=16)$ is sufficient for the qualitative research conducted, as in research projects focused on understanding common perceptions and experiences of a relatively homogenous group of individuals, 12 interviews may be sufficient, as argued by Guest, Bunce \& Johnson (2006).

The analysis of the sample shows that all 16 respondents are doctors, 15 of them men and 1 woman. Their ages range from 36 to 63 years. Twenty-five percent of the participants are under 39 years of age, $44 \%$ are between 40 and 49, 25\% are between 50 and 59 and, finally, $6 \%$ are over 60 years of age. The interviewees teach at 8 different UCLM centres on the Albacete, Ciudad Real, Cuenca and Toledo campuses, and belong to 4 different departments. Regarding their qualifications, there are 2 industrial engineers, 2 civil engineers, 1 computer engineer, 4 telecommunication engineers, 1 industrial organisation engineer, 4 graduates in physical sciences, 1 architect and 1 mining engineer.

The information was obtained through a structured interview, with questions prepared at the beginning of the research, and developed in the order indicated below, with each participant being asked in the same way. This type of interview has the advantage of being systematic, it facilitates data classification and analysis, and is also objective and reliable (Díaz-Bravo, Torruco-García, Martínez-Hernández \& Valera-Ruiz, 2013).

The interviewees ware asked the following questions:

1. What criteria do you follow when choosing the contents, you include in the talk/conference?

2. What technical means do you use at the conference?

3. What teaching materials do you deliver at the conference and when?

4. What didactic aspects do you consider when giving a lecture?

Interviews were conducted between 3 April and 15 May 2020 either face-to-face (4 interviews) or telematically (12 interviews), depending on geographical constraints and respondent preference (Baker \& Edwards, 2012; Bavaresco, D’Oca, Ghisi \& Lamberts, 2020). The reasons for the mix of data collection methods were the location of interviewees and the availability of participants (Denzin \& Lincoln, 2011), coupled with the lockdown of the population due to the COVID-19 pandemic. All interviews were recorded using a digital audio recorder for subsequent transcription and analysis.

Once the audio files had been transcribed from the recordings into written documents, they were analysed using the ATLAS.ti 8.1 programme, which facilitated the coding work and the grouping of codes into families. The programme also allows us to identify commonalities and to draw conclusions about typical themes that emerge during interviews (Gibson \& Chase, 2002), using the constant comparison procedure (Charmaz, 2006; Penalva, Alaminos, Francés \& Santacreu, 2015).

Open coding was used to name and categorise the concepts and descriptions resulting from the data analysis (Flick, 2007). The coding process produced a large number of codes, which were simplified and grouped together to avoid overcoding (Flick, 2007; Jones, 2007; Friese, 2012). These actions were performed using constant comparison, merging the codes that had different names but essentially captured the same concept or phenomenon, naming them with a name related to the research questions (Gibbs, 2012; Friese, 2012). Figures 1 and 2 show the networks of code groups obtained using ATLAS.ti 8.1.

As this is an exploratory study, the intention is not to generalise the results, but to try to interpret the aspects investigated in terms of perspective, knowledge, values, opinions, meanings and professional experiences, as closely as possible to how the interviewees perceive them (Blaxter, Hughes \& Tight, 2002; Pratt, 2009). In this process, meaning has been sought in the data in a rigorous and systematic way 
(DeCuir-Gunby, Marshall \& McCulloch, 2010; Smit, 2002), establishing relationships between data categories via interpretive analysis (Trinidad, Carrero \& Soriano, 2006).

In spite of the difficulty of being able to universalise the results (Sánchez-Flores, 2019), counting has been used as part of the analysis process, facilitating the recognition of patterns in the data that allow a certain degree of generalisation to be obtained (Sandelowski, 2001). No attempt has been made to give a numerical nature to the facts, because the aim is to find out about and describe the techniques, ideas and methods that teachers use in lectures (Sandelowski, 2001). Pronouns denoting indeterminate quantity have been used. Thus, in this work, some or few would be equivalent to the occurrence of the observed phenomenon in less than $25 \%$ of the participants and many would be equivalent to more than $75 \%$ of participants (Sandelowski, 2001), with several being understood as an intermediate term.

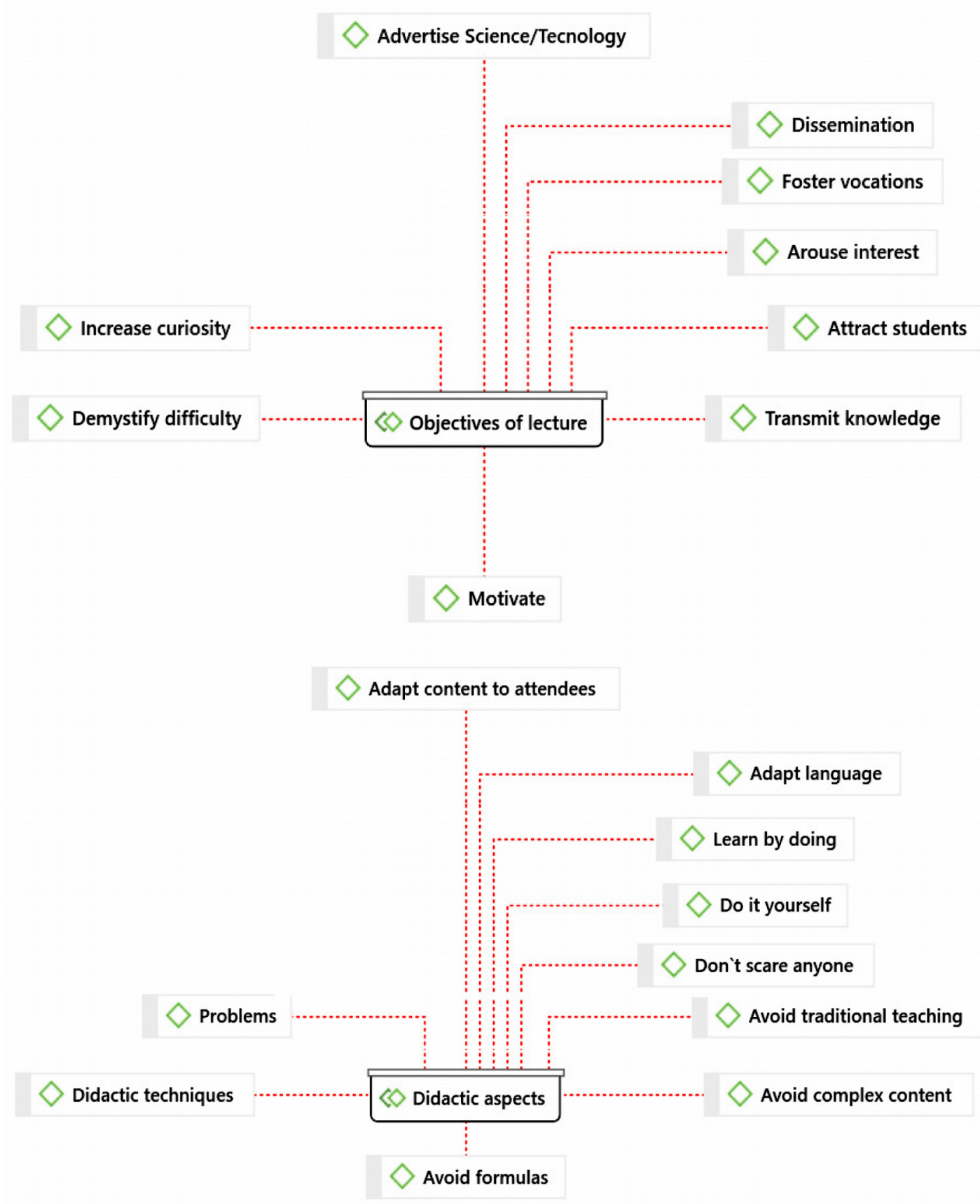

Figure 1. Networks of code groups of the Conference objectives and Didactic aspects 

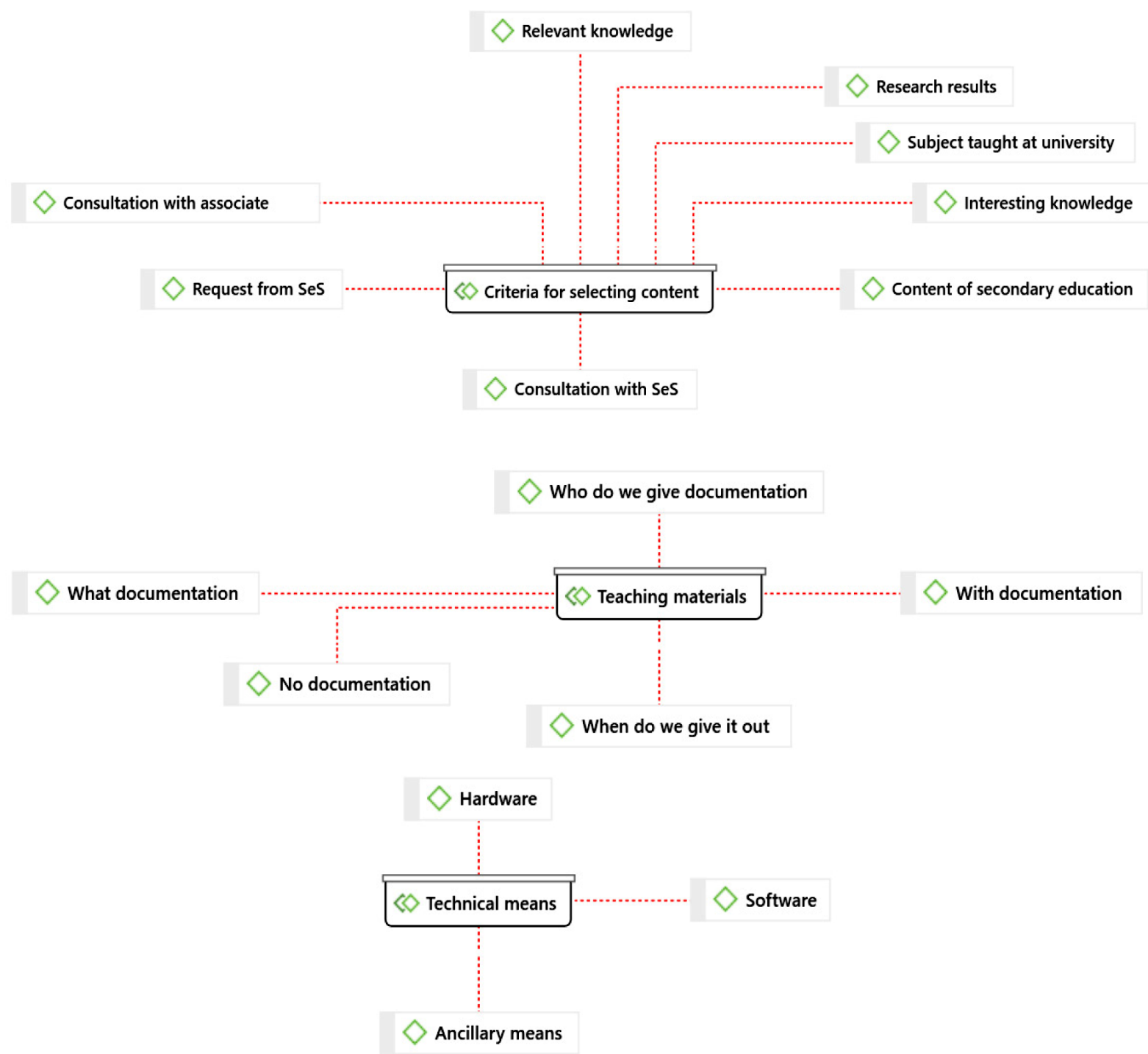

Figure 2. Networks of code groups for Content selection criteria, Teaching material and Technical means

\section{Results and Discussion}

The results of the present experience are described in detail below. For the sake of clarity, they have been divided into five main groups: 1) Objectives to be achieved with the lectures, 2) Criteria in the selection of content, 3) Didactic aspects employed, 4) Technical means foreseen, and 5) Documentation provided.

\subsection{Objectives}

The participants included in their answers some of the objectives they intend to achieve through the conferences, besides the dissemination of science and technology, which is the backbone of these actions.

Several interviewees indicate that through their lectures they seek to promote the degrees they teach in order to arouse the interest of secondary school students in these degrees and thus attract students. Others try to stimulate interest in technology, science, or try to raise their interest in engineering, regardless of their academic background: "The idea behind everything at the end is to try to promote scientific vocations or something, at least so that people don't feel so far away" (No. 9), an issue of particular importance in the previously mentioned context of scarcity of vocations for this type of degrees, mainly among the female sector, this being an aspect which, getting ahead of the conclusions, highlights the interest of this type of activities in order to reduce the gender gap as far as science is concerned (Roper, 2019). 
Thus, several participants highlighted the importance of transmitting knowledge to students who are not clear about what they are going to study in the future and to provide them with some guidance to clarify aspects, concepts or ideas related to STEM. As participant No. 16 says: "[we try] to provide something different to the kids that can give them that little flame, to start a vocation". In this way, a closer knowledge of this type of careers is made possible, through professionals in the field and not only through the information they receive via the guidance services of the school itself, groups of friends or social networks which, as Gómez, Sánchez, Reveriego and Marcos (2016) point out, may be generated by incomplete or biased information.

The aim is likewise to motivate secondary school students by trying to demystify the difficulty they associate with science and engineering degrees, trying to show them a few professional opportunities by explaining some cases and making them aware of the ramifications of this type of knowledge and the possibilities it offers, most often unknown to them due to a lack of information or contradictions in the information they have received from unreliable sources.

The transmission of information concerning the characteristics of STEM degrees, the scientific and technological advances related to them, as well as the professional development options they offer, may be of interest to secondary school students. In this regard, Gómez et al. (2016) detected great interest from those attending informative conferences on degrees related to industrial engineering. They requested more information on the areas of work of these engineering degrees in order to base their choice of future university studies. It should be borne in mind that, among other factors, vocational choice is based on a person's knowledge of themselves and of the profession (Vázquez \& Manassero, 2009) and lectures can awaken the student's vocation towards a particular degree (Vericat, Schilardi, Vela \& Salvarezza, 2013). It may be asserted that it is important to provide pre-university students with adequate information about STEM-related professions.

\subsection{Criteria Employed}

The preparation of the lectures entails important work that involves preliminary tasks such as searching for didactic material in order to have up-to-date presentations and selecting the equipment and activities that will help during the presentation (Vericat et al., 2013). Knowledge of the topic to be developed, its length and the duration of the lecture will facilitate the work prior to giving the lecture.

Approximately half of the participants report that the content of the lectures is conditioned by the request made to them by the secondary education $(\mathrm{SeS})$ teacher who contacts them, seeking to cover or complement the content of a subject taught at secondary level. When the topic to be developed is very extensive, one of the interviewees contacts the SeS teacher to consult on the issues to be included and thus define, between them, the agenda of the conference. In other cases, the lecturer gathers information on the syllabus of the secondary school subjects by consulting teachers at the SeS who teach at the university as associate lecturers, reaching a situation similar to the previous point, with the limitation of being a more generalist approach and not as specific as when talking directly to the teacher of the group to which the lecture will be given.

In addition, by limiting the contents of the conference to the requirements of the secondary school, it can be used as a non-formal education tool that serves to reinforce and collaborate with formal education in secondary school subjects (Doddoli, 2007). The contents chosen should inform and seek to raise awareness, such that the attendees obtain an expanded knowledge at the end of the lecture, allowing them to discuss the topic among themselves and with their acquaintances (Florensa, Martí, Kumar \& Carrasco, 2013; Vericat et al., 2013).

On some occasions SeS teachers ask the interviewee to describe the results of the research they are carrying out. "Normally they would ask me to tell them a little bit about research and things we were doing in research and interesting things we were doing at the university. So I would tell them what I was doing at the time in the field of research" (No. 8). 
The lack of connection between many of the contents covered in formal science and technology education and the reality that students know may be a factor in their lack of interest in STEM (Blanco, 2004). Providing them with a learning opportunity without the restrictions of formal curricula, in which novel and interesting science and technology topics are presented, may spark their interest, inciting their curiosity towards science and engineering (Toharia \& Lowy, 2004).

When university centres are the ones to prepare the catalogue of outreach lectures to be given to secondary schools, it is the lecturers who choose the topic to be covered. Here, the criteria followed by the participants to select the contents are varied, although they normally focus on aspects in which they are experts or include the subjects they teach at the university, adapting, as mentioned above, the content to the target audience. They try to include content that is impactful, novel, that arouses the interest of the audience and/or that may be useful, but always seeking to motivate them towards the technique, science or engineering in which the interviewee teaches: "we go to topics that may draw them to our field and that may arouse their interest" (No. 12).

In the selection of content, participants try to ensure that the content has personal relevance for students, so that they make connections with their lives; that it has professional relevance, to provide them with a picture of possible careers; and finally, that it has social significance, so as to clarify the purpose of science in human and social affairs (Mei, Kaling, Xinyi, Sing \& Khoon, 2007).

In order for these dissemination activities to be interesting for the secondary schools and for their teachers to be able to justify them without problems, one of the participants proposed as a strategy that the lectures should cover some content of a subject, as well as the evaluation criteria and the assessable learning standards, using the official curriculum published in the official state gazette (Royal Decree 1105/2014, of 26 December, which establishes the basic curriculum of Compulsory Secondary Education and the Baccalaureate) "[We need to] Adapt our lectures, not to what we understand might be interesting, but exactly to what would suit the teacher. If you use the methodology applied in secondary education, then it is also useful for the evaluation" (No. 7).

\subsection{Didactic Aspects}

When selecting the content and preparing the material to be included in the lecture, most participants adapt the content to the age and grade level of the audience and recommend not to use equations and formulas and to avoid complicated aspects of the topics presented. Regardless of the level of education, but especially in times of transition and as we approach higher education, we have to keep in mind that we need to speak the language of our students so that the planning is constructively aligned (González-Geraldo \& Del Rincón, 2013).

Constructive alignment is a concept coined by John Biggs, reported in González-Geraldo and Del Rincón (2013), which highlights the need to align what is planned with what is carried out and what is evaluated, especially through evaluation and with special attention to the use of verbs, which trigger cognitive, affective and volitional processes. By saying that planning should be constructively aligned, we are highlighting the need that the efforts before, during and after the proposed activities be directed towards the same objectives.

Regarding the use of equations, one participant recalls the words of Dr. Stephen Hawking in his speech when he received the Prince of Asturias Award: "you have to bear in mind what the master Hawking said when he wrote $A$ Brief History of Time: 'for every extra formula I put in I halve the sales', because this is a bit like that" (No. 10). Several participants agree with the same idea, stating that any difficulties or problems that might frighten secondary school students should be avoided by showing the contents in a more visual and practical way. This situation is due to the negative attitudes that students develop towards the formal and mathematical approach to science because of its abstract and complex nature (Tseng et al., 2013). In essence, one can attempt to replicate the aims of Faraday's Christmas Lectures given to young 
people at the Royal Institution of London, which were intended to "amuse and entertain, as well as educate, edify, and above all, inspire" (Reif, 2001: page 61).

They also recommend adapting the language to be used in the presentation to the audience in order to facilitate the dissemination of science: "the idea is to reach people and for the content to reach them, and for that you have to use the right language" (No. 9). As Pisano et al. (2017) point out, there is a problem in any kind of dialogue when communication is established between research specialists and non-specialists, hence the adaptation of the language used and the means employed in the conference are essential to make the content fulfil its mission.

Participants underscore the importance of keeping in mind that the target audience is not students of science or engineering, and they therefore consider that simple vocabulary should be used to get the message across. This can be a problem for the teacher, as many recognise that there is a risk in explaining the content of the lecture as is normally done in university lectures. In particular, participant No. 8 recommends: "You have to go down several steps to reach them, using another language that you don't normally use". They recognise that you need to have the ability to explain difficult concepts in simple terms (Spronken-Smith, Brodeur, Kajaks, Luck, Myatt, Verburgh et al., 2013).

During the lecture it is hard to keep students' interest for long (Seguí, Poza, \& Mulet, 2015), so participants use techniques to capture their attention. One way to achieve this is to look for shocking contents of the lecture and relate it to literature and science fiction films, as participant No. 15 does: "I start with Terminator or Star Wars, then they get excited and get hooked". Others look for current news related to the subject of the lecture "to get the kids more involved" (No. 7).

Some participants recommend applying different didactic tactics in order to increase and maintain the interest and involvement of conference attendees. Thus, participant No. 9 suggests: "You have to start teaching them little things that get their attention and then, if you want, explain it to them, to the level of depth you need, but first you have to get them hooked."

Others propose developing active activities during DIY type conferences, with the aim of getting attendees to actively participate in the development of the conference and to get them involved in it: "It's not like going to give a talk and that's it. No, I go there, I launch a challenge, I let you work, you think and I help you to solve it so that in some way you can see what you can contribute" ( $\left.\mathbb{N}^{\circ} 12\right)$. The lecture is used to engage students in a formative activity with positive learning-by-doing effects, allowing participants to process new knowledge and actively partake in the activity (Gya \& Bjune, 2021).

Related to the previous technique, another participant likes to apply the experiential learning technique, commonly known as "learning by doing": "instead of arriving and giving a lecture with a master class, we bring a series of activities, first we explain some theory in order to develop those activities and then we let them be the participants of what they have learned" (No. 13). This pedagogical approach allows us to improve not only the student's participation in the activity, but also their motivation, and it makes it easier for them to update their knowledge on a specific topic under the supervision of experts (Uskov, Bakken \& Aluri, 2019).

In addition to the above, several interviewees stress the importance that the conference should not be approached as a lecture in which a large amount of information and data is conveyed to them. As Seguí et al. (2015) point out, lectures are similar to teaching a class, but they are not the same thing. If the goal is to retain students who may be interested in STEM, the quality of the learning experience must be enhanced (Gibson \& Chase, 2002), without undermining the message to be conveyed by reducing its quality or accuracy.

\subsection{Technical Means}

As regards the technical means used during the lectures, all the participants report that they use a laptop computer, presentations prepared with Microsoft PowerPoint and, in some cases, even the projector and a 
screen. They also use a remote control with a laser pointer to show the slides without having to stand next to the computer, an aspect that directly affects the pedagogical climate that they wish to create; this didactic strategy helps the teacher move around during the presentation, allowing them to walk among the participants and prevent them from having to remain seated or not moving during the activity (Seguí et al., 2015).

Many of them insert videos in the presentation or prepare them with a large number of images that help to convey the content, in an attempt to make the talk more dynamic and entertaining. The material used to make the slides is a hybrid of electronic, digital means, etc., which help the speaker to convey the message (Jenkins, 2012). Optimal presentations try to convince the audience with key messages and non-verbal communication (Doumont, 2005).

Multimedia slides are one of the most widely used technologies in the dissemination of science. The stimulation of the senses by integrating sound, graphics, video, text and animation allows one to keep the audience attentive, while at the same time facilitating the transmission of information visually and not only verbally (Espinoza \& Rincón, 2004). In any case, the medium should always be chosen by the lecturer according to the characteristics of the subject to be addressed, trying to make the presentation as didactic as possible (Espinoza \& Rincón, 2004).

Over half of the participants say that they also use equipment or prototypes that allow students to visualise the concepts explained in the talk, such as 3D printers, models of seismic buildings, models of bridges, water models, augmented reality glasses, sand-boxes, shaking tables, Arduino boards and robots of different types and sizes. The use of this type of equipment helps them capture the students' attention, as participant No. 15 states when he shows them the result of programming a robot: "it is so visual that the kids love it." In addition, the strategy of introducing the use of equipment in the lectures pursues the didactic practice of applying the theoretical concepts covered in the lecture with real equipment, products or substances, which makes them feel more motivated and participative during the lecture.

Following this same philosophy, some participants try to develop experiments that students can later replicate, as participant No. 16 explains: "I try to use basic means so as not to surprise the students with big set-ups, but rather with accessible material that they can then tinker with at home."

The use of technical means and emerging technologies ( for instance robotics, information technology, electronics, etc.), means that conferences are not only used to transmit information, but also as a vehicle that involves the attendees in the use and application of this information, covering different areas of knowledge with activities that affect thinking, reasoning, feeling, action and even personal interactions (Dickson, 2004; Ribeiro, Godoy, Belini \& de Souza-Filho, 2018).

\subsection{Documentation}

There is no uniform behaviour when it comes to providing the information discussed at the dissemination conference. Slightly more than half of the participants provide some kind of documentation on the content of the presentation, while the rest choose not to give out any documents at all.

When the answer is negative, the reasons for not providing documentation are not usually stated, except for a couple of participants, one of whom considers that it is not necessary to give out any material since the aim of the informative talk is to generate students' interest. In the other case, participant No. 9 states: "I prefer that people pay attention to what I'm telling them."

In the group of teachers who do provide documentation, there are two different behaviours. Some of them provide the documentation, after giving the talk, if requested to do so by the secondary school, while others provide it directly to the teacher who contacted them.

As a general rule, the information is sent after the lecture has been given, although there are also cases in which it is sent to the SeS teacher beforehand, so that they have it in advance. In some cases, they have 
only been asked for a short summary, as a table of contents, listing the main sections to be covered, so that the students can use it as a script during the lecture.

The documentation provided usually consists of the same presentation used to deliver the lecture and/or links to the videos that are shown during the lecture.

\section{Conclusions}

In an attempt to alleviate the lack of vocations of secondary school students towards STEM degrees, many initiatives are being carried out by companies and universities, among which we can include the scientific-technical dissemination conferences that are the subject of this work.

In this research, by means of structured interviews with 16 university lecturers involved in these actions, we try to describe the didactic aspects of these actions and how they are planned with a view to capturing the attention of secondary school students and igniting in them the flame that may become the engine that awakens in them a vocation for this type of disciplines.

From the analysis of the objectives pursued by the different lecturers when they give this type of lectures, we can highlight the promotion of the degrees in which they carry out their academic activity, the promotion of scientific vocations, the transmission of knowledge and the demystification of this type of teaching.

When selecting the topics to be addressed, the participants try to align them with the secondary school curriculum, or show results of their research at the express request of the secondary schools. When the lecture programme is developed by the university itself, lecturers try to deal with topics of interest and motivation for secondary school students. The openness with which they present and discuss their experiences is also reflected in the way they adapt to the target audience.

In preparing the content to be included in the lecture, the age and course of the audience is therefore taken into account, avoiding aspects such as equations or formulas and seeking a more visual or practical presentation, always adapting the speech to the target audience and capturing their attention by using examples with which they are familiar.

Lectures are usually delivered through computer-supported presentations, with the use of prototypes, models or equipment that allows for testing or for the students themselves to develop their own knowledge by carrying out small challenges proposed by the lecturer.

There is no uniformity in terms of the documentation provided by the lecturers, there being cases where it is provided and others where it is not. Each participant justifies their choice, trying to give priority to the transmission of the content.

There has been no attempt to assess the appropriateness of the practices, methods, techniques, ideas, opinions or criteria that have appeared in the analysis of the interviews. These variables may be conditioned by the academic training and professional background of the interviewees, the characteristics of the subject matter of the conference, as well as the approach that each participant wishes to give to the activity.

It is hard to say which practice, method, approach or technique used to deliver the lectures is the most effective for disseminating science and engineering. Each interviewee has answered the questions posed on the basis of what they perceive to be most effective and/or useful when carrying out the activity. The results found will allow other teachers to know some criteria, techniques, ideas or didactic practices that they can use, adapting them based on their criteria, knowledge to be explained and/or characteristics of the group of students attending the dissemination activity.

There are also a series of biases and limitations that must be taken into account when opening up future lines of action, such as the perception and the meaning that students, paying special attention to variables such as age and gender, display when receiving these types of talks, and the educational objectives that secondary school teachers who use these actions to promote STEM are trying to achieve. 
We propose that future lines of research should be developed to measure the effectiveness and degree of satisfaction of teachers and lecturers when using the different options described in this text.

\section{Declaration of Conflicting Interests}

The authors declared no potential conflicts of interest with respect to the research, authorship, and/or publication of this article.

\section{Funding}

The authors received no financial support for the research, authorship, and/or publication of this article.

\section{References}

Bavaresco, M.V., D’Oca, S., Ghisi, E., \& Lamberts, R. (2020). Methods used in social sciences that suit energy research: A literature review on qualitative methods to assess the human dimension of energy use in buildings. Energy Build, 209, 1-19. https://doi.org/10.1016/j.enbuild.2019.109702

Baker, S.E., \& Edwards, R. (2012). How many qualitative interviews is enongh? Expert voices and early career reflections on sampling and cases in qualitative research. National Centre for Research Methods (NCRM).

Blanco, A. (2004). Relaciones entre la educación científica y la divulgación de la ciencia. Revista Eureka sobre Enseñanza y Divulgación de las Ciencias, 1(2), 70-86.

https://doi.org/10.25267/Rev_Eureka_ensen_divulg_cienc.2004.v1.i2.01

Blaxter, L., Hughes, C., \& Tight, M. (2002). Cómo se bace una investigación (2nd ed.).Gedisa.

Bonfil, M. (2003). Una estrategia de guerrilla para la divulgación: Difusión cultural de la ciencia. In Congreso Latinoamericano Ciencia, comunicación y sociedad, Centro Nacional de Alta Tecnología (24-26), Costa Rica.

Broder, E.D., Guilbert, K.E., Tinghitella, R.M., Murphy, S.M., Ghalambor, C.K., \& Angeloni, L.M. (2019). Authentic science with dissemination increases self-efficacy of middle school students. Integrative and comparative biology, 59(6), 1497-1508. https://doi.org/10.1093/icb/icz140

Bryant, A., \& Charmaz, K. (2007). The SAGE Handbook of Grounded Theory. SAGE Publications Ltd. https://doi.org/10.4135/9781848607941

Çalıs, S. (2020). Physics-chemistry preservice teachers' opinions about preparing and implementation of STEM lesson plan. Journal of Technology and Science Education, 10(2), 296-305.

https://doi.org/10.3926/jotse.971

Carvalho, L., Scott, L., \& Jeffery, R. (2005). An exploratory study into the use of qualitative research methods in descriptive process modelling. Information and Software Technology, 47(2), 113-127.

https://doi.org/10.1016/j.infsof.2004.06.005

Chacko, P., Appelbaum, S., Kim, H., Zhao, J., \& Montclare, J.K. (2015). Integrating Technology in STEM Education. Journal of Technology and Science Education, 5(1), 5-14. https://doi.org/10.3926/jotse.124

Charmaz, K. (2006). Constructing Grounded Theory. A practical guide through qualitative analysis. SAGE.

Corredor, N., \& Socorro, M.A. (2014). Impacto de las tecnologías de información y comunicación en la divulgación del conocimiento científico. Revista Arbitrada del Centro de Investigación y Estudios Gerenciales, 5(2), 139-161.

DeCuir-Gunby, J.T., Marshall, P.L., \& McCulloch, A.W. (2010). Developing and using codebook for the analysis of interview data: An example from a professional development research Project. Field Methods, 23(2), 136-155. https://doi.org/10.1177/1525822X10388468

Denzin, N.K., \& Lincoln, Y.S. (2011). The SAGE handbook of qualitative research (4th ed.). SAGE. 
Díaz-Bravo, L., Torruco-García, U., Martínez-Hernández, M., \& Valera-Ruiz, M. (2013). La entrevista, recurso flexible y dinámico. Investigación en Educación Médica, 2(7), 162-167. https://doi.org/10.1016/S20075057(13)72706-6

Dickson, D. (2004). Science and technology communication for development. PLoSBiology, 2(1), 28-29. https://doi.org/10.1371/journal.pbio.0020011

Doddoli, C. (2007). Las conferencias de divulgación como un vehículo de la educación no formal. In X Reunión de la Red de Popularización de la Ciencia y la Tecnología en América Latina y el Caribe (RED POP - UNESCO) y IV Taller "Ciencia, Comunicación y Sociedad” (1-10), Costa Rica.

Doumont, J. (2005). The Cognitive Style of PowerPoint: Slides Are Not All Evil. Technical Communication, 52(1), 64-70. https://www.jstor.org/stable/43089160

Dutta-Moscato, J., Gopalakrishnan, V., Lotze, M.T., \& Becich, M.J. (2014). Creating a pipeline of talent for informatics: STEM initiative for high school students in computer science, biology, and biomedical informatics. Journal of Pathology Informatics, 5, 1-12. https://doi.org/10.4103/2153-3539.129448

Espinoza, N., \& Rincón, A.G. (2004). Las presentaciones multimedia en el ámbito científico. El profesional de la información, 13(5), 374-381. https://doi.org/10.1080/13866710412331323725

Flick, U. (2007). Introducción a la investigación cualitativa. Ediciones Morata.

Florensa, C., Martí, M., Kumar, C., \& Carrasco, S. (2013). “The magic of light!” - An entertaining optics and photonics awareness program. In Education and Training in Optics and Photonics (paper EWF2, 1-8). Optical Society of America. https://doi.org/10.1117/12.2070738

Friese, S. (2012). Qualitative data analysis with ATLAS.ti. SAGE Publications.

Fuentes, J., Huertas, P., \& Torres, A.M. (2019). Promoción de la ciencia, la tecnología, la ingeniería y las matemáticas (STEM). El Proyecto Precampus. ENSAYOS. Revista de la Facultad de Educación de Albacete, 34(2), 101-121.

Fuesting, M.A., Diekman, A.B., \& Hudiburgh, L. (2017). From classroom to career: The unique role of communal processes in predicting interest in STEM careers. Social Psychology of Education, 20(4), 875-896. https://doi.org/10.1007/s11218-017-9398-6

Gómez, P.A., Sánchez, E., Reveriego, J.A., \& Marcos, S. (2016). Divulgación de la ingeniería industrial entre los alumnos de $3^{\circ}$ y $4^{\circ}$ de ESO y Bachillerato en las provincias de Salamanca, Ávila, Cáceres, Toledo. Available at: https://gredos.usal.es/bitstream/handle/10366/126918/MID 14 236.pdf? sequence=1 (Accessed: August 2021).

González-Geraldo, J.L., \& Del Rincón, B. (2013). Aprendiendo el lenguaje de nuestros alumnos: de las competencias al aprendizaje. Cadernos de Pedagogia no Ensino Superior, 24, 25-41.

González-Geraldo, J.L. (2014). Hacia una universidad más humana. ¿Es superior la educación superior? Biblioteca Nueva.

González-Geraldo, J.L., Trevitt, C., \& Carter, S. (2011). Realising pedagogical potential of the Bologna Process Third Cycle. Journal of Technology and Science Education, 1(2), 16-23.

https://doi.org/10.3926/jotse.2011.22

Guest, G., Bunce, A., \& Johnson, L. (2006). How many interviews are enough? An experiment with data saturation and variability. Field Methods, 18(1), 59-82. https://doi.org/10.1177/1525822X05279903

Gibson, H.L., \& Chase, C. (2002). Longitudinal impact of an inquiry-based science program on middle school students' attitudes toward science. Science Education, 86(5), 693-705.

https://doi.org/10.1002/sce.10039

Gibbs, G. (2012). El análisis de datos cualitativos en investigación cualitativa. Madrid: Ediciones Morata. 
Gya, R., \& Bjune, A.E. (2021). Taking practical learning in STEM education home: Examples from do-it-yourself experiments in plant biology. Ecology and Evolution, 11, 3481-3487.

https://doi.org/10.1002/ece3.7207

Handcock, M.S., \& Gile, K.J. (2011). Comment: On the concept of snowball sampling. Sociological Methodology, 41(1), 367-371. https://doi.org/10.1111/j.1467-9531.2011.01243.x

Iglesias, N., García-Frank, A., \& Fesharaki, O. (2017). Ideas y reflexiones para una divulgación científica efectiva. Boletín de la Real Sociedad Española de Historia Natural, Sección Aula, Museos y Colecciones, 4, 29-41.

Izcara, S.P. (2014). Manual de investigación cualitativa. Editorial Fontamara.

Jackson, M.C., Leal, C.C., Zambrano, J., \& Thoman, D.B. (2019). Talking about science interests: the importance of social recognition when students talk about their interests in STEM. Social Psychology of Education, 22(1), 149-167. https://doi.org/10.1007/s11218-018-9469-3

Jenkins, E. (2012). Death by PowerPoint? A Media Ecology Examination of the Debates Over Slideware. Explorations in Media Ecology, 10(3-4), 225-245. https://doi.org/10.1386/eme.10.3-4.225_1

Jones, M.L. (2007). Using software to analyse qualitative data. Malaysian Journal of Qualitative Research, 1(1), 64-76.

Kearney, C. (2011). Efforts to Increase Students' Interest in Pursuing Science, Technology, Engineering and Mathematics Studies and Careers. National Measures taken by 21 of European Schoolnet's Member Countries - 2011 Report. Brussels: European Schoolnet (EUN Partnership AISBL).

Kilty, T., Burrows, A., Welsh, K., Kilty, K., McBride, S., \& Bergmaier, P. (2021). Transcending disciplines: Engaging college students in interdisciplinary research, integrated STEM, and partnerships. Journal of Tecbnology and Science Education, 11(1), 146-166. https://doi.org/10.3926/jotse.1139

King, A.J., Fisher, A.M., Becich, M.J., \& Boone, D.N. (2017). Computer Science, Biology and Biomedical Informatics Academy: Outcomes from 5 Years of Immersing High-School Students into Informatics Research. Journal of Pathology Informatics, 8, 1-12. https://doi.org/10.4103/2153-3539.201110

Luzón, A., \& Sevilla, D. (2010). Presentación del monográfico: la Agenda de Lisboa en el proceso de construcción europea. Revista Española de Educación Comparada, 16, 15-21.

Marques, J.C., Restivo, M.T., \& Chouzal, M.F. (2012). Mentoring Activities in a Summer School. International Journal of Engineering Pedagogy (iJEP), 3(S1) (16-21). https://doi.org/10.3991/ijep.v3iS1.2407

Martínez, M. (2006). La investigación cualitativa (síntesis conceptual). Revista de Investigación en Psicología, 9(1), 123-146. http://hdl.handle.net/123456789/1598

Moscovici, A.M., \& Petrica, I. (2015). Socio-Educational and scientific-technical aspects of the architectural presentation of spaces intended for religious act in Romania. Procedia-Social and Behavioral Sciences, 197, 1140-1147. https://doi.org/10.1016/j.sbspro.2015.07.368

Murphy, C., \& Beggs, J. (2006). Co-teaching as an approach to enhance science learning and teaching in primary schools. The Science Education Review, 5(2), 63:1-63:10.

Mei, Y.T.G., Kaling, C., Xinyi, C.S., Sing, J.S.K., \& Khoon, K.N.S. (2007). Promoting science process skills and the relevance of science through Science Alive! Programme. In Proceedings of Redesigning Pedagogy: Culture, Knowladge and Understanding Conference, Singapore. Environmental \& Science Education, 3(1), 30-34.

Nuño, T., \& Rico, A. (2013). ZIENTZIARI SO-Mirando a la ciencia, un programa para la promoción de vocaciones científico-tecnológicas superando los estereotipos de género en niñas y niños de la Comunidad Autónoma del País Vasco (CAPV). In IX Congreso Internacional sobre Investigación en Didáctica de las Ciencias (2539-2544). Girona.

Orrico, E. (2012). The memory of scientific divulgation: An information discourse. Morpheus - Revista Eletrônica em Ciências Humanas, 9(14), 128-144. 
Osborne, J. (2007). Engaging young people with science: Thoughts about future direction of science education. Promoting scientific literacy: Science education research in transaction. In Linder, C., Östman, L., \& Wickman, P.O. (Eds.), Proceedings of the Linnaeus Tercentenary Symposium held at Uppsala University (105-112). Uppsala, Sweden.

Pacheco, M.F. (2003). La divulgación de la ciencia. CIENCIAS, 71, 56-64.

Paz, M. (2003). Investigación cualitativa en educación. Fundamentos y tradiciones. Editorial McGraw Hill.

Penalva, C., Alaminos, A., Francés, F.J., \& Santacreu, O.A. (2015). La investigación cualitativa: técnicas de investigación y análisis con Atlas.ti. PYDLOS Ediciones.

Pisano, R., Franckowiak, R., \& Anakkar, A. (2017). Reading Science, Technology and Education: A tradition dating back to Science into the History and Historiography. Transversal: International Journal for the Historiography of Science, 3, 77-97. https://doi.org/10.24117/2526-2270.2017.i3.07

Pratt, M.G. (2009). For the lack of a boilerplate: Tips on writing up (and reviewing) qualitative research. Academy of Management Journal, 52(5), 856-862. https://doi.org/10.5465/amj.2009.44632557

Reif, S. (2001). Michael Faraday: de encuadernador a hombre de ciencia. Ingeniería y Competitividad, 3(1), 50-72. https://doi.org/10.25100/iyc.v3i1.2336

Revuelta, C.A. (2012). Cultura Científica: la ciencia como actividad creativa y de inclusión. Experiencias en la Facultad de Ingeniería Química de la Universidad Nacional del Litoral. Fundamentos en Humanidades, 13(26), 259-268.

Ribeiro, A.V., Godoy, G.C., Belini, L., \& de Souza-Filho, M.P. (2018). Holografía y realidad virtual en la enseñanza de nanotecnología: Nuevos horizontes dirigido a educación secundaria. MOMENTO. Revista de Física, 56, 34-45.

Riesco, M., \& Cernuda, A. (2015). Reflexiones sobre la promoción de los estudios universitarios en Informática. In Actas de las XXI Jornadas de la Enseñanza Universitaria de la Informática. Andorra La Vella.

Rittmayer, M.A., \& Beier, M.E. (2009). Self-Efficacy in STEM. In Bogue, B. \& Cady, E. (Eds.). Applying Research to Practice (ARP) Resources. Available at: http://www.engr.psu.edu/AWE/ARPresources.aspx

Roper, R.L. (2019). Does gender bias still affect women in science? Microbiol Mol Biol, 83(3), 1-9. https://doi.org/10.1128/MMBR.00018-19

Sahin, A. (2013). STEM clubs and science fair competitions: Effects on post-secondary matriculation. Journal of STEM Education, 14(1), 5-11.

Sánchez-Flores, F.A. (2019). Fundamentos epistémicos de la investigación cualitativa y cuantitativa: consensos y disensos. Revista Digital de Investigación en Docencia Universitaria, 13(1), 102-122. https://doi.org/10.19083/ridu.2019.644

Sandelowski, M. (2001). Real qualitative researchers do not count: The use of numbers in qualitative research. Research in Nursing \&Health, 24(3), 230-240. https://doi.org/10.1002/nur.1025

Seguí, J.M, Poza, J.L., \& Mulet, J.M. (2015). Estrategias de divnlgación cientifica. Editorial Universitat Politècnica de València.

Serrate, S., Martín, J., Caballero, D., \& Muñoz, J.M. (2020). Responsabilidad universitaria en la implementación de los objetivos de desarrollo sostenible. European Journal of Child Development, Education and Psychopathology, 7(2), 183-196. https://doi.org/10.30552/ejpad.v7i2.119

Shevtshenko, E., Karaulova, T., Igavens, M., Strods, G., Tandzegolskiené, I., Tūtlys, V. et al. (2017).

Dissemination of Engineering Education at Schools and its Adjustment to Needs of Enterprises. In Proc. of the 28th DAAAM International Symposium (44-53), Vienna. https://doi.org/10.2507/28th.daaam.proceedings.006 
Smit, B. (2002). Atlas.ti for qualitative data analysis. Perspectives in Education, 20(3), 65-76. https://hdl.handle.net/10520/EJC87147

Spronken-Smith, R.A., Brodeur, J.J., Kajaks, T., Luck, M., Myatt, P., Verburgh, A. et al. (2013). Completing the research cycle: A framework for promoting dissemination of undergraduate research and inquiry. Teaching and Learning Inquiry, 1(2), 105-118. https://doi.org/10.2979/teachlearninqu.1.2.105

Tabares-Quiroz, J., \& Correa-Vélez, S. (2014). Tecnología y sociedad: una aproximación a los estudios sociales de la tecnología. CTS: Revista Iberoamericana de Ciencia, Tecnología y Sociedad, 9(26), 129-144.

Taylor, S.J., \& Bogdan, R. (1992). Introducción a los métodos cualitativos de investigación. Paidós.

Toharia, M., \& Lowy, E. (2004). Divulgación y educación científica en la escuela y en los centros interactivos de la ciencia. In Rubia, F.J., Fuentes, I., \& Casado, S. (Eds.), Percepción Social de la Ciencia (263-295). España: Academia Europea de Ciencias y Artes.

Trinidad, A., Carrero, V., \& Soriano, R. (2006). Teoría fundamentada “Grounded Theory". La construcción de la teoría a través del análisis interpretacional. Cuadernos Metodológicos, 37. Centro de Investigaciones Sociológicas.

Trumper, R. (2006). Factors affecting junior high school students' interest in physics. Journal of science Education and Technology, 15(1), 47-58. https://doi.org/10.1007/s10956-006-0355-6

Tseng, K.H., Chang, C.C., Lou, S.J., \& Chen, W.P. (2013). Attitudes towards science, technology, engineering and mathematics (STEM) in a project-based learning ( $\mathrm{PjBL}$ ) environment. International Journal of Technology and Design Education, 23(1), 87-102. https://doi.org/10.1007/s10798-011-9160-x

Tynybekovna, S., Meirbekovich, K., Talgatovna, B., \& Pernebaevna, G. (2013). To the using the information and computer technology for specialist's competitive training in high school. Procedia - Social and Behavioral Sciences, 89, 213-217. https://doi.org/10.1016/j.sbspro.2013.08.836

Urraco, M. (2007). La metodología cualitativa para la investigación en Ciencias Sociales. Una aproximación "mediográfica". Intersticios. Revista Sociológica de Pensamiento Crítico, 1(1), 99-126.

Uskov, V.L., Bakken, J.P., \& Aluri, L. (2019). Crowdsourcing-based learning: the effective smart pedagogy for STEM education. In 2019 IEEE Global Engineering Education Conference (EDUCON) (1552-1558). IEEE. https://doi.org/10.1109/EDUCON.2019.8725279

Vázquez, A., \& Manassero, M.A. (2009). Patrones actitudinales de la vocación científica y tecnológica en chicas y chicos de secundaria. Revista Iberoamericana de Educación, 50(4), 1-15.

Vericat, C., Schilardi, P.L., Vela, M.E., \& Salvarezza, R. (2013). Estrategias de difusión de nanociencia y nanotecnología en distintos sectores de la sociedad en argentina. Revista Digital Universitaria, 14(3), 1-13.

Published by OmniaScience (www.omniascience.com)

Journal of Technology and Science Education, 2022 (www.jotse.org)

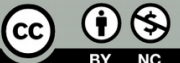

Article's contents are provided on an Attribution-Non Commercial 4.0 Creative commons International License. Readers are allowed to copy, distribute and communicate article's contents, provided the author's and JOTSE journal's names are included. It must not be used for commercial purposes. To see the complete licence contents, please visit https://creativecommons.org/licenses/by-nc/4.0/. 